\title{
Failure of Zoned Earth Dam (An analysis of earth dam break)
}

\author{
Abdul-Hassan K. Al-Shukur \\ Department of Civil Engineering, College of Engineering, University of Babylon, Babylon, \\ Iraq \\ dr_alshukur@yahoo.com \\ Ranya Badea' Mahmoud \\ Department of Civil Engineering, College of Engineering, University of Babylon, Babylon, \\ Iraq \\ ranya.bsh93@gmail.com
}

Submission date:- 7/2/2019

Acceptance date:- 5/3/2019

Publication date:-4/4/2019

\begin{abstract}
One of the most common type of embankment dam failure is the dam-break due to overtopping. In this study, the finite elements method has been used to analyze seepage and limit equilibrium method to study stability of the body of an earthfill dam during the flood condition. For this purpose, the software Geostudio 2012 is used through its subprograms SEEP/W and SLOPE/W. Al-Adhaim dam in Iraq has been chosen to analysis the 5 days of flood. It was found that the water flux of seepage during the flood reaches about $8.772 * 10^{-5} \cdot \mathrm{m}^{3} / \mathrm{sec}$ when the water level $146.5 \mathrm{~m}$ at $2^{\text {nd }}$ day. Seepage through the embankment at maximum water level increased by $55.1 \%$ from maximum water level. It was concluded that the factor of safety against sliding in downstream side decrease with increasing water level and vice versa. It was also concluded that the deposits are getting more critical stability during the conditions of flood when the factor of safety value reaches 1.219 at $2^{\text {nd }}$ day.
\end{abstract}

Keywords: Transient, Flood, Dam break, Failure, Zoned earth dam.

\section{Introduction}

Seepage is believed to be the most important cause for failure of the embankment dam, abnormal seepage conditions occurred during the intense rainfall and flooding effected significantly in the stability of the embankment slopes. Therefore, it is important that the stability and seepage analysis for the potential failure slopes with some extreme conditions. There are number of studies concerning on the issue, such as [1] Abo, A. (2001) studied seepage in earth dam by using F.E.M. He used a package program written in Fortran language. The program computed quantity of seepage and the phreatic line, pore water pressure and total head in homogeneous and zoned dams. The accuracy of the program was investigated. The program was applied to several dams and the results showed acceptable accuracy. In addition to this, the efficiency of the filter in earth dam and its importance in decreasing pressure in the dam and its effect on the amount of seepage was studied. [2] Chugh, A. K., (2013) examined the stability of a circular earth dam for radial cracking potential and static slope stability using continuum mechanics-based three-dimensional numerical models. Comparisons of numerical model results for a circular water tank with vertical walls and different radii with their analytical counterparts are included to support the validity of the ideas and their implementation in the continuum mechanics-based computer program used. Effects of sloping wall faces and Poisson"s ratio on computed deformations and stresses are also included. The same numerical models were used to assess stability of a circular dam in terms of factor of safety and associated failure surface. Three-dimensional slope stability analysis results were compared with continuum based two-dimensional slope stability analysis results to assess the magnitude of 3D effects. Example problems are included to illustrate the use of ideas presented. The need to study the slope stability of earthfill dams during drawdown is necessary and imperative not only for the existing dams, but also for the design and construction other earthfill dam projects in the region. In this paper, the rapid drawdown condition is investigated by the finite element method for AlAdhaim dam. The stability of the dam slopes is traced during the change in water level. [3] Riazi, 
K. a. (2015) used a finite element method through a computer program, named SEEP/W. In their study, Survey effect of the clay core in seepage from nonhomogeneous earth dams by changing of the core permeability, and the results showed the flow rate increases with increasing upstream head and decreases with increasing flow rate through the downstream head. Leakage rate has been reduced to a level $93.72 \%$ equal to the core permeability of the 10-6 to 10-9, and Leakage flow rate was increased to a value of $92.28 \%$, in the dam has a filter compared with no filter dam. This is due to changes in core permeability of the filter permeability.

Description of Case Study: Al-Adhaim dam is an earth dam located at a distance of $(1.5 \mathrm{~km})$ in the rear of the place in which Tuz Jay and the river Al-Adhaim merge, which is considered as seismically active region in Iraq. It consists of embankment with length of $(3.1 \mathrm{~km})$ from the helm of a major cross-river valley (where it is $73.5 \mathrm{~m}$ ) high and go through or underneath spending and channel spillway, and the payment of the wings in the left and right and up the embankment major backs on the left and right where appropriate height is less because of high natural land there. AlAdhaim dam is a fill soil with sloping core; its architecture has been developed initially by Bennie and Partners Company. The soil of the foundation consists of sloping layers from sandstone and marl uneven thickness [4]. Figure (1) shows section of the dam, which has a base level of about 70 $\mathrm{m}$ above the sea level, and the level at the top of dam is $146.5 \mathrm{~m}$. the earth dam location at $34^{\circ} 20^{\prime} 7.44^{\prime \prime} \mathrm{N}, 44^{\circ} 18^{\prime} 20.16^{\prime \prime}$ E. Table1 show the properties of each layer of the dam.

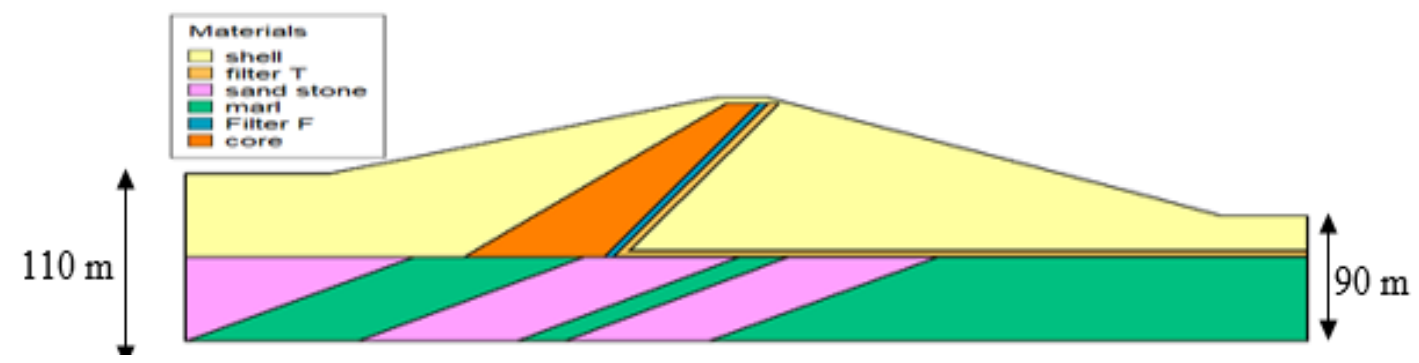

Figure 1Typical Cross Section of Al Adhaim Dam

Table 1 Material properties of Al Adhaim Dam

\begin{tabular}{|c|c|c|c|c|c|}
\hline \multicolumn{2}{|c|}{ Material zone } & $\begin{array}{c}\mathrm{E} \\
\left(\mathrm{MN} / \mathrm{m}^{2}\right)\end{array}$ & $v$ & $\begin{array}{c}\mathrm{C} \\
\left(\mathrm{KN} / \mathrm{m}^{2}\right)\end{array}$ & $\phi$ (Degree) \\
\hline \multicolumn{2}{|c|}{ Shell } & 19 & 0.3 & 0 & 37 \\
\hline \multicolumn{2}{|c|}{ Core } & 30 & 0.3 & 45 & 25 \\
\hline \multirow{2}{*}{ Filter } & Filter F & 19 & 0.3 & 0 & 35 \\
\cline { 2 - 6 } & Filter T & 19 & 0.3 & 0 & 35 \\
\hline \multirow{2}{*}{ Foundation } & Marl & 350 & 0.33 & 600 & 10 \\
\cline { 2 - 6 } & Sandstone & 300 & 0.33 & 0 & 38 \\
\hline
\end{tabular}

\section{Analysis of Normal condition}

Before start the analysis of transient state of flooding condition, the normal dam conditions were analyzed with steady-state seepage analysis and the initial conditions for the transient analysis were obtained. Boundary conditions are defined by the total head along the upstream slope, zero pressure at the toe of the downstream slope and the potential seepage face, the water level in the upstream is considered maximum (i.e.143 m.a.s.l). The dark blue line in figures 1 and 2 represents the phreatic surface in the dam during normal conditions. The phreatic surface is low throughout the dam and exits at the dam toe, which is desirable for stability. Figures show that the total head on the left is larger than the total head on the right. The total head difference creates a water flow from the left to the right. The head and pressure distributions are demonstrated in Figures 2 and 3, respectively. Velocity vectors (the black arrows) refer for the seeping water and the total flux through the dam. The highest velocity was obtained $2.7316^{*} 10-5 \mathrm{~m} / \mathrm{s}$ and Total Flux was $3.9155^{*} 10-5 \mathrm{~m} 3 / \mathrm{sec}$. The free surface elevation drops from $143 \mathrm{~m}$ to $95 \mathrm{~m}$ at the boundary of core, which reflects the efficiency of the core as anti-seepage device. 


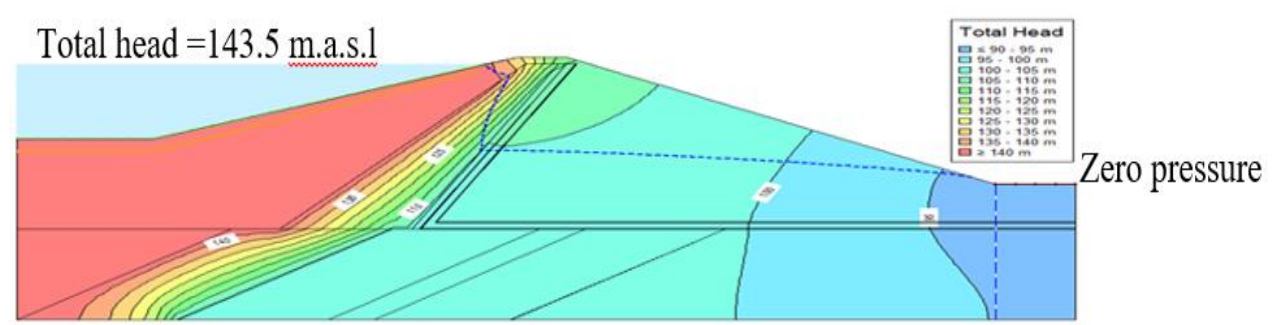

Figure 2 Contour lines of Total head with maximum water level

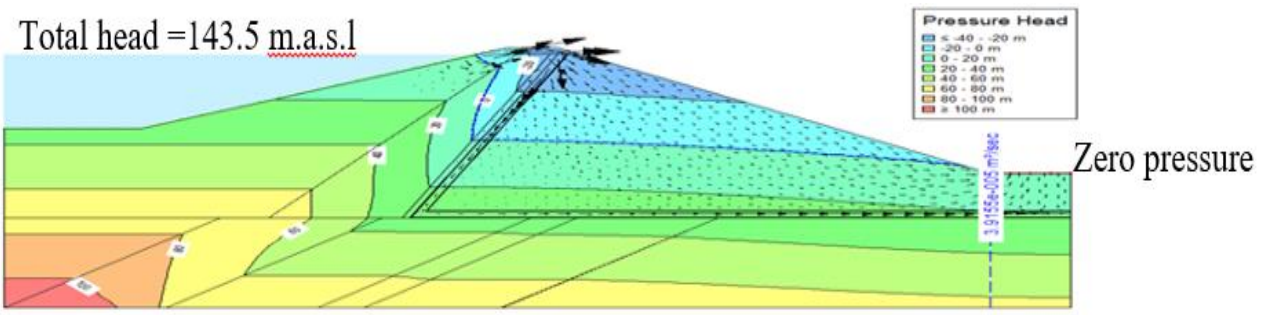

Figure 3 Contour lines of Pressure head and flow vectores with maximum water level $=143,\left(Q=3.915 * 10^{-5} \mathrm{~m}^{3} / \mathrm{sec}\right)$

Stability analysis has been done with Mohr-Coulomb method to explain the state of soil, Factor of safety is calculated using Morgenstern-Price method as shown in figure 4.

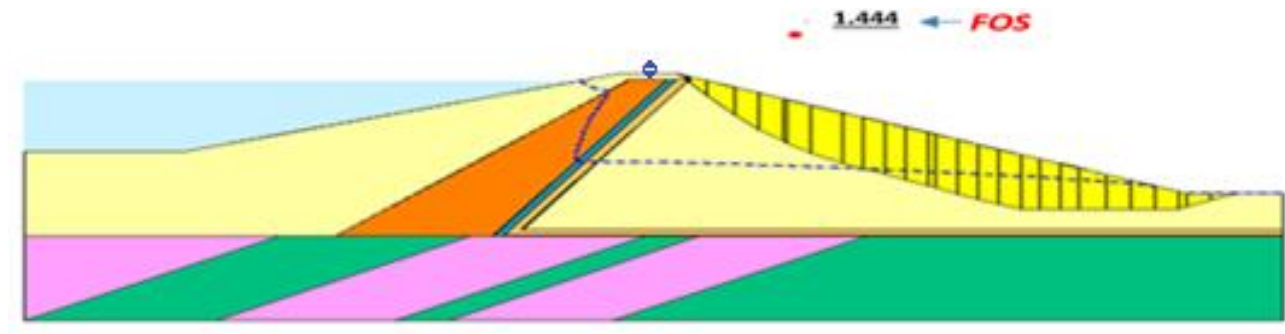

Figure 4 the Most critical slip surface (composite slip surface) in downstream side for maximum water level in reservoir, $(\mathrm{FOS}=1.444)$

\section{Analysis of flooding condition}

The transient analysis is actually an unsteady analysis. It can take the steady state as the initial condition. During the flood, the water level of the dam is assumed above the normal conditions and the front of the water table extend up to specific point, which lies in the middle of the crest of the dam. Therefore, the boundary condition defined by the pressure head is extended by adding lines, which represents the normal condition. In a particular analysis, the GeoSlope program allows to import the results, which obtained from another analysis result to define

The functions as well as the boundary conditions. So, the transient analysis could be done based on the steady-state analysis as the parent analysis. Therefore, the pressure head and the pore water pressure at each node, which obtained from the steady-state analysis, are transferred to the transient analysis as the boundary condition. The soil above the phreatic surface assumed dry. The properties of the soil such as permeability, which defined in the steady-state analysis, also imported to the transient analysis. Initially the time duration for the analysis was defined as 5 days with 5 time steps and the time increment was selected as linear manner. Every time step in the model was saved and the times which corresponding to the significant changes in the flow properties were taken as the results. In this study, the seepage analysis of the Al-Adhaim dam considered in case of gradual change in the water level. Figures (5),(6),(7),(8) and (9) show the seepage condition at 1st, 2nd, 
3 th , 4th and 5th day of flooding respectively. (A very useful boundary function is userspecified Head versus Time). Consider figures (5)-(10) where the gradual change of water level in the reservoir is to be applied as a boundary condition so that the dissipation or pore-water pressures in the dam can be modelled. The advantage of using a Head versus Time function on the reservoir side of the dam is that it avoids a "shock" unloading of the water pressure on the dam if the water level in the reservoir were instantly drawn down. Whenever possible, it is a good idea to apply changing boundary Conditions as realistically as possible, to avoid shocking the system [5].During the process gradual change of the water level to different elevations, unstable seepage was formed in the soil body. The pore-water pressures at different points continuously changed, and the unsaturated region continuously reflected that the location of phreatic line intermittently dropped and tended to be stable with the elongation of the time. The figures (5) to (9) show the location of phreatic surface, total head and pressure head for the previous cases. After 1st day the water table is increased $1.5 \mathrm{~m}$, after $2 \mathrm{nd}$ day it increased to $3.5 \mathrm{~m}$ above the maximum water table and interact the top of the profile at (at the mid-point of crest), then it increased by $2 \mathrm{~m}$ at $3 \mathrm{rd}$ day while it reduced by $3 \mathrm{~m}$ below the initial water table at 4 th day and finally it reach $0.5 \mathrm{~m}$ above the initial level at the 5 th day. The blue dashed lines refer to the locations phreatic surface during different period of flooding as in Figures 5 to 10.

\section{5 m.a.s. 1}

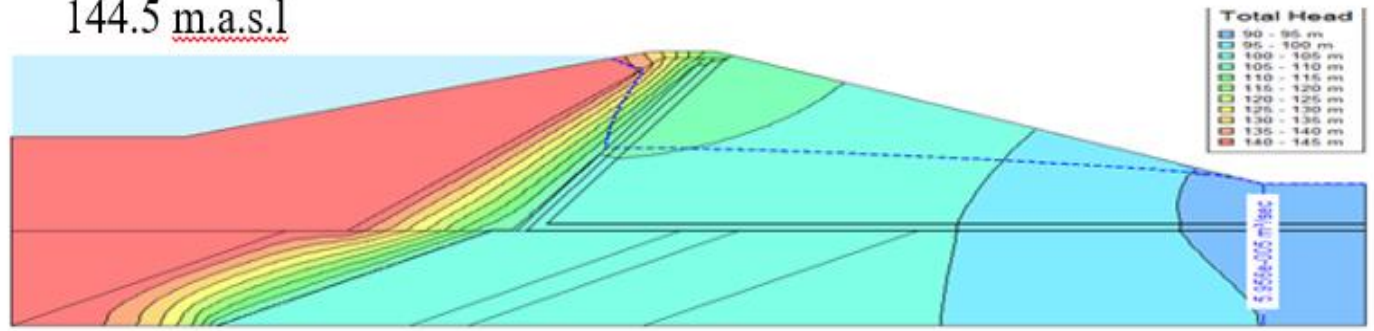

Figure 5 Contour lines of Total head through the $1^{\text {st }}$ day. Water elevation $=144.5 \mathrm{~m}$, $\mathrm{Q}=5.95 * 10^{-5} \mathrm{~m}^{3} / \mathrm{sec}$

\section{5 m.a.s. 1}

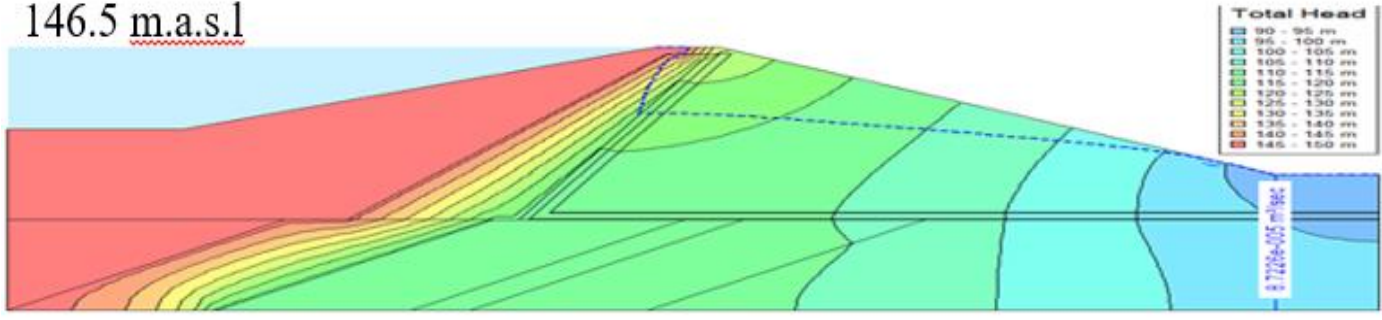

Figure 6 Contour lines of Total head through the $2^{\text {nd }}$ day, Water elevation=146.5 $\mathrm{m}$, $\mathrm{Q}=8.722 * 10^{-5} \mathrm{~m}^{3} / \mathrm{sec}$

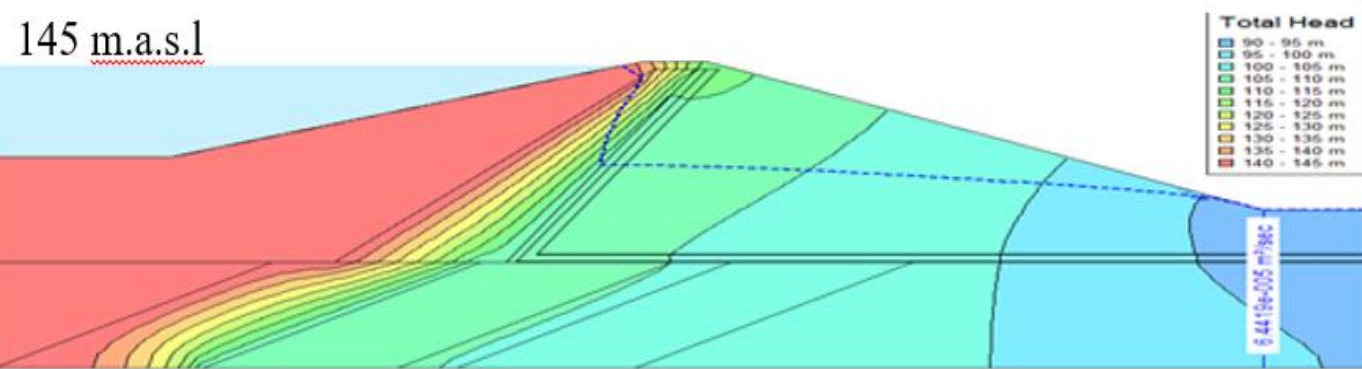

Figure 7 Contour lines of Total head through the $3^{\text {rd }}$ day, Water Elevation $=145 \mathrm{~m}$, $\mathrm{Q}=6.44 * 10^{-5} \mathrm{~m}^{3} / \mathrm{sec}$ 
140 m.a.s.1

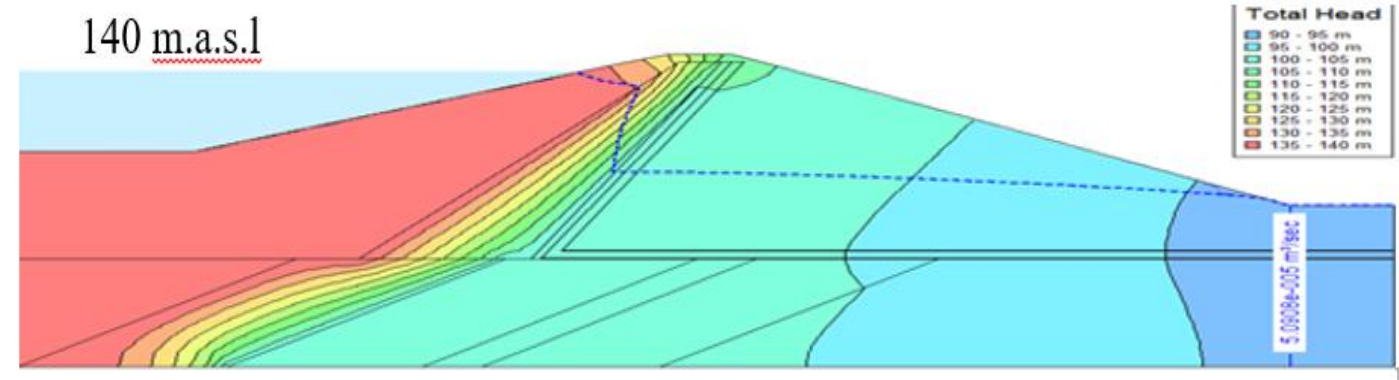

Figure 8 Contour lines of Total head -7 through the $4^{\text {th }}$ day, Water elevation=140 $\mathrm{m}$, $\mathrm{Q}=5.09 * 10-\mathrm{m}^{3} / \mathrm{sec}$

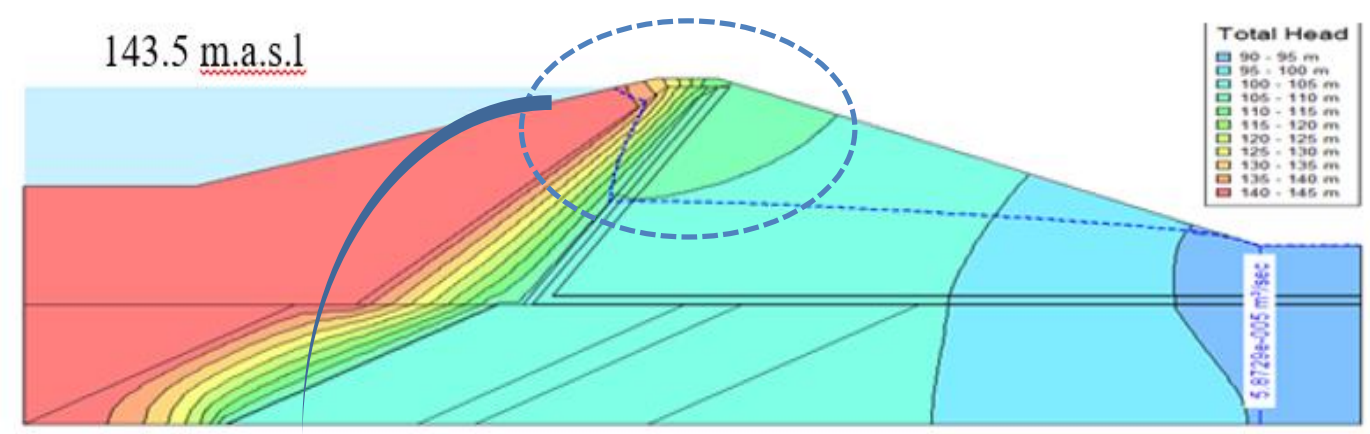

\section{Figure 9 Contour lines of Total head through the $5^{\text {th }}$ day, Water elevation $=143.5 \mathrm{~m}$}

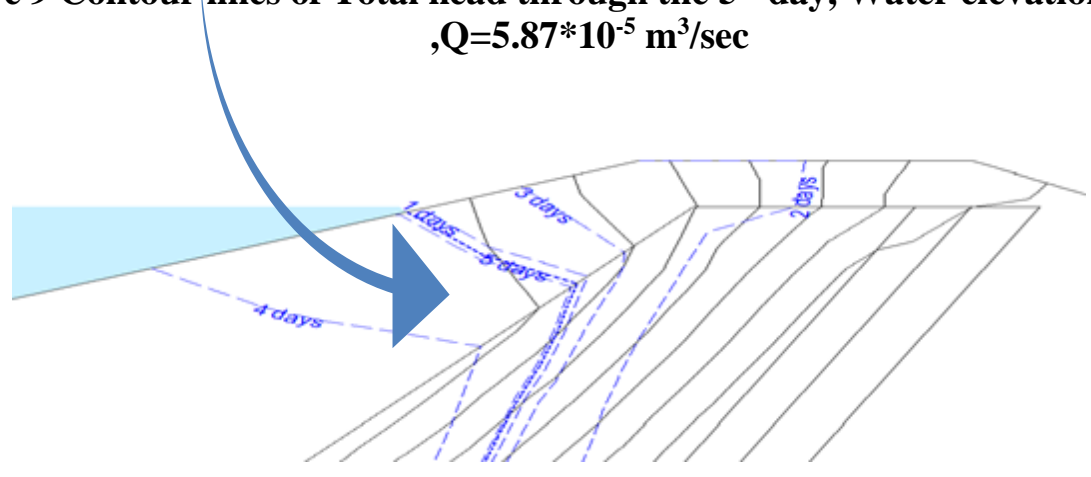

Figure 10 the locations of phreatic surface during different period of

From the previous time intervals the water flux increased from $3.915^{*} 10-5 \mathrm{~m} 3 / \mathrm{sec}$ at the initial stage to $5.95 * 10-5 \mathrm{~m} 3 / \mathrm{sec}$ then it reach $8.722 * 10-5 \mathrm{~m} 3 / \mathrm{sec}$ after that it becomes $6.44 * 10-5$ $\mathrm{m} 3 / \mathrm{sec}$ then $5.09 * 10-5 \mathrm{~m} 3 / \mathrm{sec}$ and last $5.87 * 10-5 \mathrm{~m} 3 / \mathrm{sec}$.It show the seepage through the deposit is increased because of the increasing head difference. Pervious figures show the seepage conditions for various time periods after the flooding. The water table tends to elevate continuously until a certain time period and then lowered near the initial position. The seepage through the deposit also shows same variation as the water table. These changes happened because of the increasing head at the upstream side. Forward and backward movement of the total head contours clearly indicates the pressure changes.

After 1st day of flooding, the water flux was just above the water flux which corresponds to the initial condition. After a certain period it reached a maximum and then started to reduce. It is because that during the intense rainfall, the head at the upstream side increased rapidly caused an abnormal increase in the seepage. Total flux changes during dam break in table 2.

Therefore the normal steady - state condition of the dam has been lost. Once the rainfall disappeared, the dam intends to reach the steady-state condition back. When the steady-state reached, the total flux never changes with the time. 
Table 2 The total flux changes during Flood condition

\begin{tabular}{|c|c|c|}
\hline Time Period & Water Level $(\boldsymbol{m})$ & Total Flux $\left.\mathbf{m}^{3} / \mathbf{s e c}\right)$ \\
\hline $1^{\text {st }}$ day & 144.5 & $5.95^{*} 10^{-5}$ \\
\hline $2^{\text {nd }}$ day (max.flux) & 146.5 & $8.722^{*} 10^{-5}$ \\
\hline $3^{\text {rd }}$ day & 145 & $6.44 * 10^{-5}$ \\
\hline $4^{\text {th }}$ day & 140 & $5.09 * 10^{-5}$ \\
\hline $5^{\text {th }}$ day & 143.5 & $5.87 * 10^{-5}$ \\
\hline
\end{tabular}

The $S E E P / W$ program helps to analyse the various pressure conditions, flow conditions and the changes in the material properties at any point or region of the embankment. The pressure condition could be analysed in different forms such as total pressure, pressure head and pore-water pressure. Here, some nodes from the geometry item called potential seepage face have been selected for the analysis. Figure 11 shows the nodes on the potential seepage face which are selected for the analysis of pressure variation. SEEP/W program allows generating the graphs with distance and time as independent variables

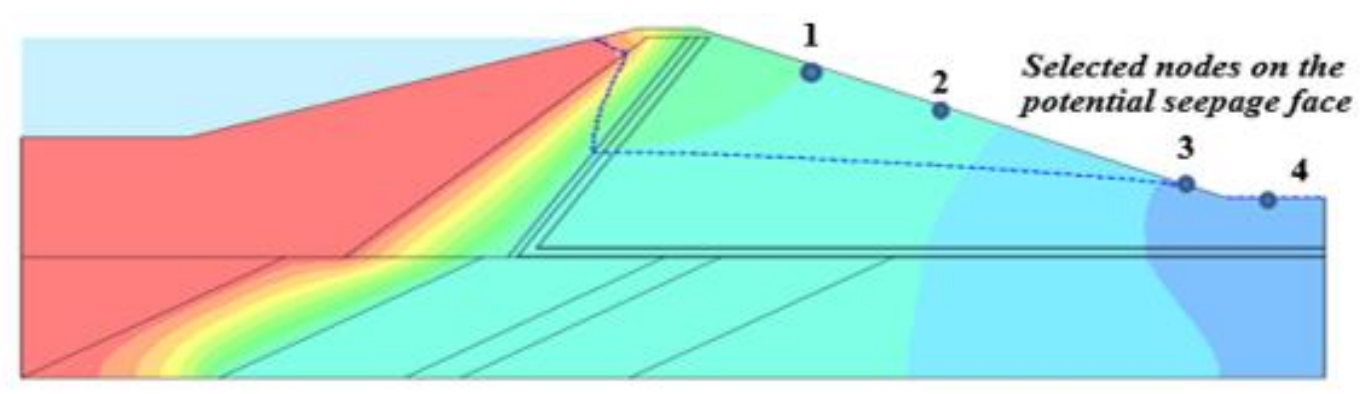

Figure 11 Location of selected nodes on the potential seepage face

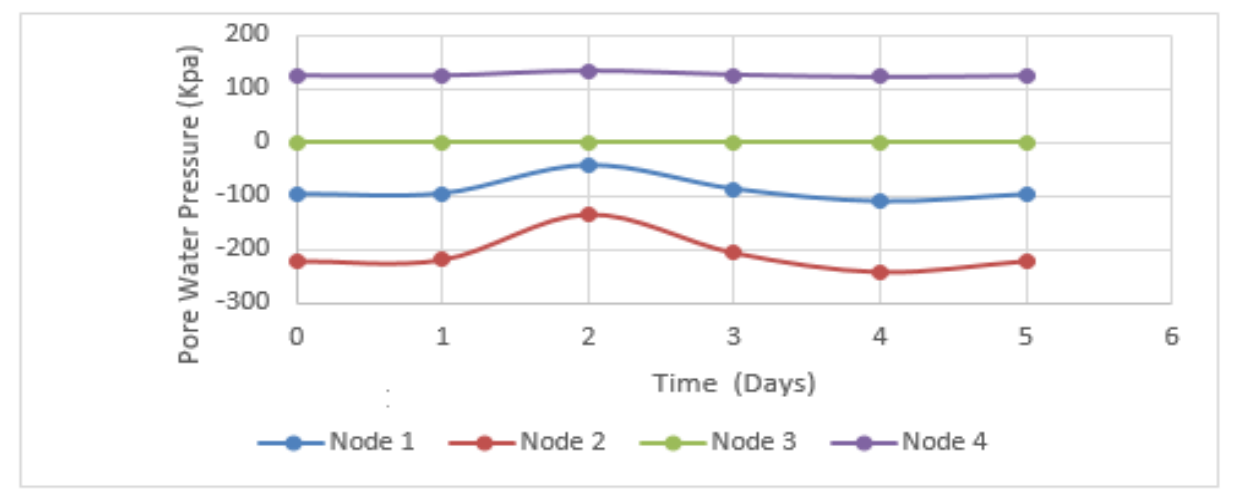

Figure 12 Changes of Pore-water pressure with time at potential seepage face

Figure (12) show the pore - water pressure changes for 5 days in 4 nodes on the potential seepage face is shown in the figure above. Pore-water pressure changes all nodes are similar way. The node at the bottom of the geometry (node 4) always has higher pore-water pressure than other nodes on the seepage potential face, because the node is saturated at all. But the increasing seepage caused an elevation in the graph. The pore-water pressure which corresponding the other nodes will be below the curve which related to node 4 at any time of the analysis and arrange themselves according to the degree of saturation at each nodes. 


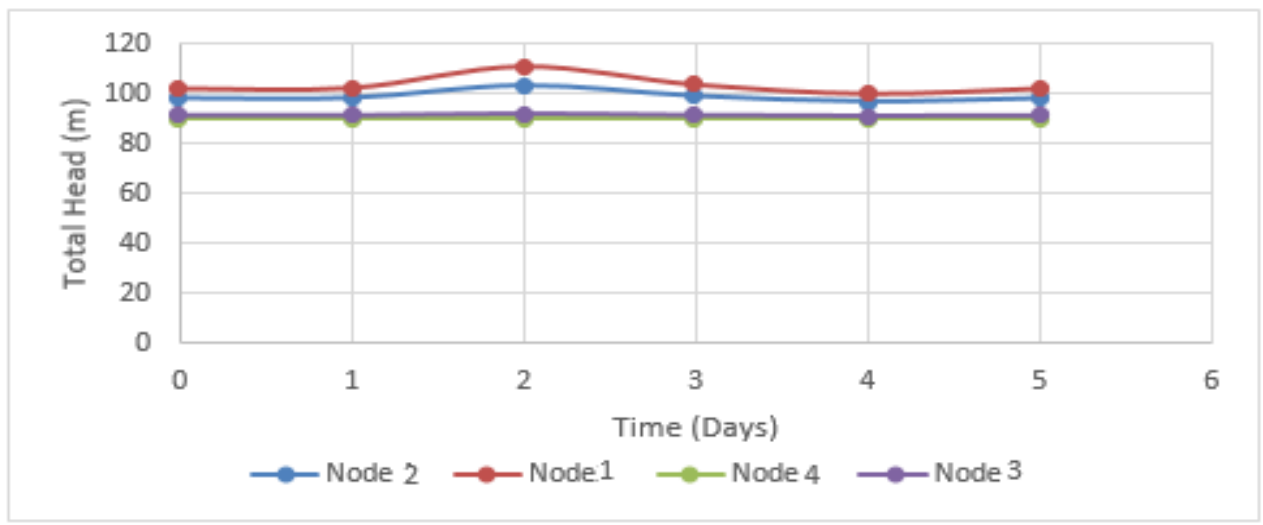

Figure 13 Total head changes with time and distance at potential seepage face

Figure 13 shows the changes of total head for 5 days and distance at same nodes on the potential seepage face. The node at the bottom of the of the downstream slope (node 4) is defined as a smallest head among the other points. If we take any other node on the toe of the downstream side, it will be defined as a boundary condition of zero pressure. Total pressure at the other nodes are change with time where it is being above the water table (they will have the same value if their location was below the water table). At all other nodes, the total pressure continuously increase with time until the water table reaches to the maximum and then started to reduce.

Transient analysis is used to know how long the embankment takes to responds for a given boundary condition. Therefore, the fundamental flow properties (pressures and water flow rate) will vary with time. The analysis required an initial boundary condition as well as a destination boundary condition. During the transient seepage analysis, we have seen that the pressures have different values for different time periods. Therefore, the stability of the embankment should be analyzed for some different time periods in order to find possible slides during the flood. The stability analysis has been done by SLOPE/W together with the SEEP/W (transient analysis) in a same project. The material properties and the pore-water pressure conditions are assigned from the transient analysis for the particular time period.

The stability has been analyzed for different time periods after the flood. They are 1st, 2nd, 3rd, 4th and 5th day (last time). All the analysis carried out based on Morgenstern-price method. The factor of safety was obtained for each analysis with keeping the same slip surface for all analysis. Stability conditions for each time period are shown in figures 14 to 18 .

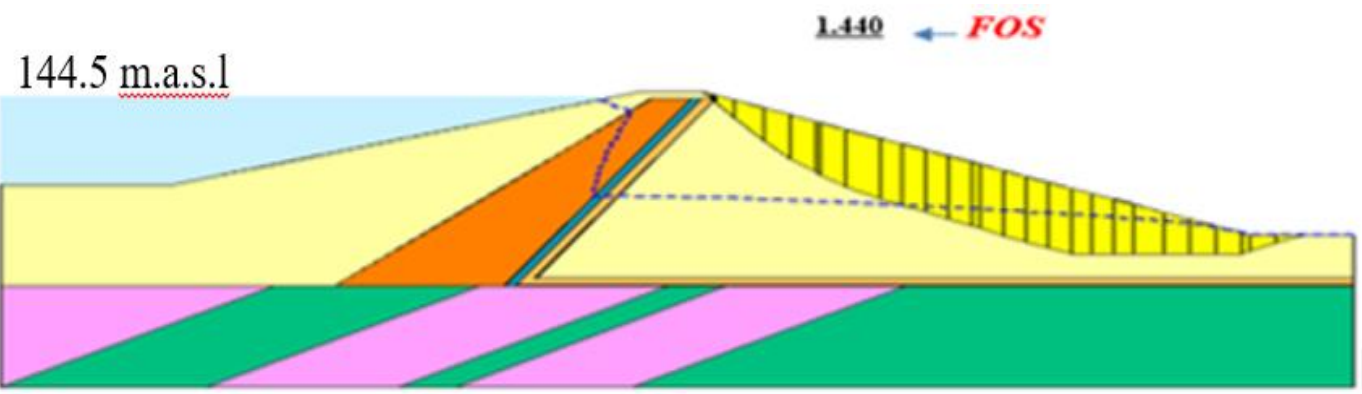

Figure 14 show the stability of earthen dam (downstream) during $1^{\text {st }}$ day of the flooding condition, (FOS=1.44). 


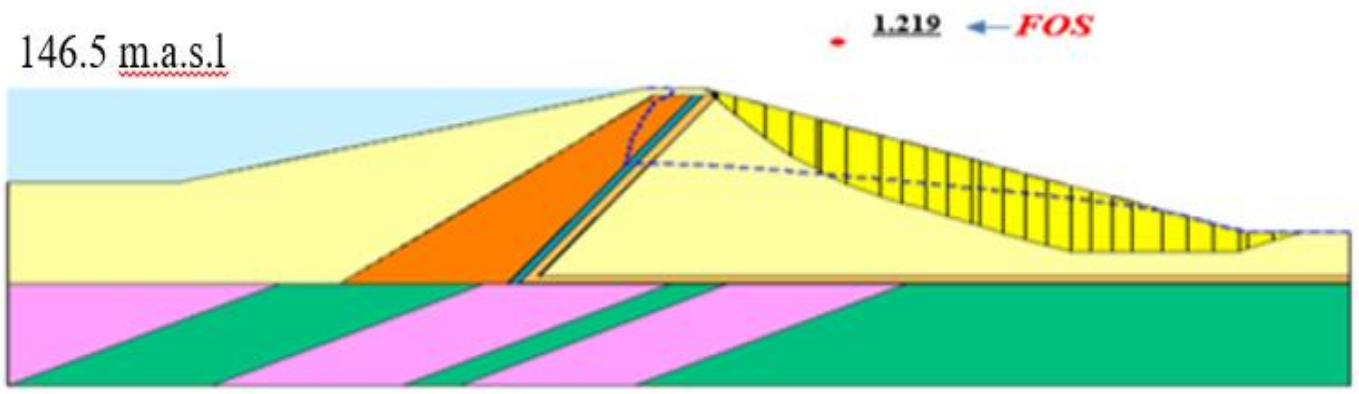

Figure 15 show the stability of earthen dam (downstream) during $2^{\text {nd }}$ day of the flooding condition, $(\mathrm{FOS}=1.219)$.

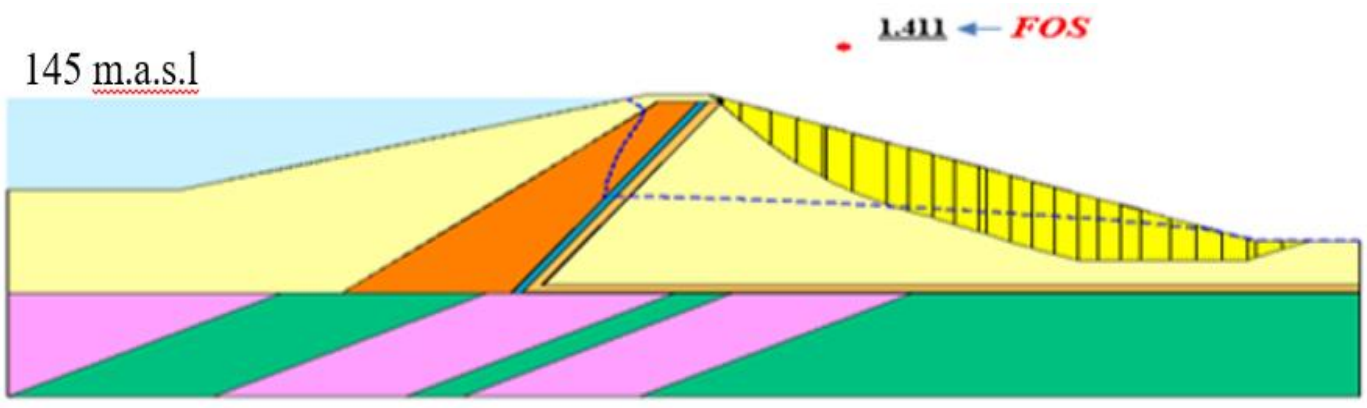

Figure 16 show the stability of earthen dam (downstream) during $3^{\text {rd }}$ day of the flooding condition, $(\mathrm{FOS}=1.411)$.

$$
\text { - } 1.489 \leftarrow \text { FOS }
$$

\section{0 m.a.s.1}

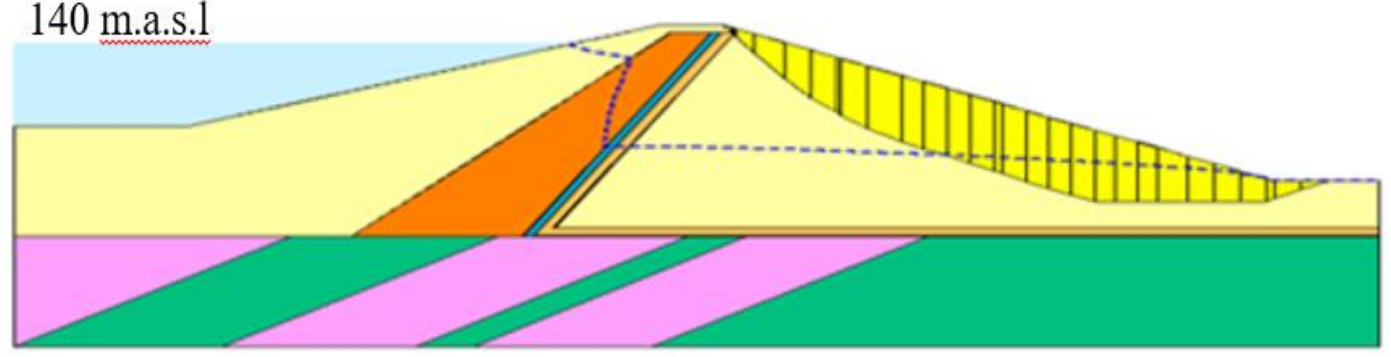

Figure 17 show the stability of earthen dam (downstream) during $4^{\text {th }}$ day of the flooding condition, FOS $=(1.489)$

\section{5 m.a.s.1}

$$
\text { - } 1.445 \leftarrow F O S
$$

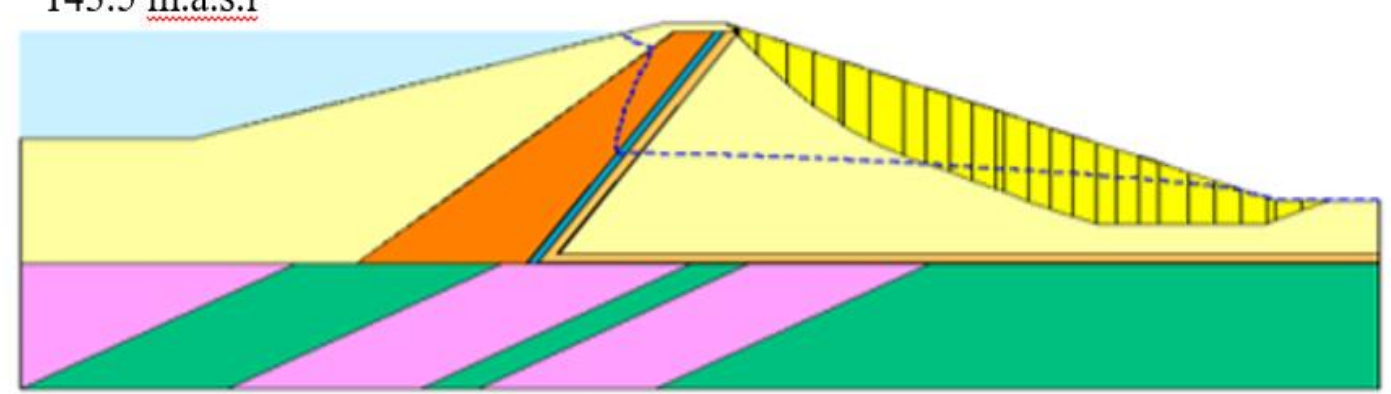

Figure 18 show the stability of earthen dam (downstream) during $5^{\text {th }}$ day of the flooding condition, $(\mathrm{FOS}=1.445)$. 
Journal of University of Babylon for Engineering Sciences, Vol. (27), No. (1): 2019.

Table 3 Factor of safety against sliding for flooding Condition analysis (at Downstream)

\begin{tabular}{|c|c|c|}
\hline Time, (day) & Water level,$(\mathrm{m})$ & Factor of Safety \\
\hline 1 day & $144.5 \mathrm{~m}$ & 1.440 \\
\hline 2 day & $146.5 \mathrm{~m}$ & 1.219 \\
\hline 3 day & $145 \mathrm{~m}$ & 1.411 \\
\hline 4 day & $140 \mathrm{~m}$ & 1.489 \\
\hline 5 day & $143.5 \mathrm{~m}$ & 1.445 \\
\hline
\end{tabular}

Table 3 shows factor of safety against sliding for each analysis. The factor of safety is decreases until the increase of water table and then increasing until the end of the analysis. The results show that the slope is potentially unstable throughout the flooding. It is because the increasing pore-water pressure reduces the shear strength of the soil and the saturation of water reduces the frictional strength.

\section{Conclusions}

1. Seepage analysis results show the values of seepage through the embankment increased by 55.1 $\%$ from maximum water level (maximum water level=143 m).

2. Water flux during maximum condition was $3.915^{*} 10^{-5} \mathrm{~m}^{3} / \mathrm{sec}$ and it is increased up to $5.87 * 10^{-5}$ $\mathrm{m}^{3} / \mathrm{sec}$ at the end of flooding condition, so the amount of increase is $33.3 \%$ at the end of transient state. This shows that the deposit is not well compacted.

3. From stability analysis it shown that the FOS increased with the decreasing of water level in downstream zone

4. During the flood, factor of safety was reduced to 1.219 , which shows, the deposits are getting more critical stability during the conditions the flood.

\section{CONFLICT OF INTERESTS.}

- There are no conflicts of interest.

\section{References}

[1] Abo, A.. "Calculation seepage through earth dams by finite element method". M.Sc., Thesis, Department of Civil Engineering,College Of Engineering, University of Baghdad, 2001.

[2] Chugh, A. K. "Stability Assessment of a Circular Earth Dam", International Journal for Numerical and Analytical Methods in Geomechanics, Vol. 37, 17, pp. 2833-2859, 2013.

[3] Riazi, K. a. "Investigation the effect of clay core in seepage from non-homogenous earth dams". Journal of Scientific Research and Development, Vol.5, No.2, PP.280-285, 2015.

[4] SEEP/W, M. " Seep modelling". Users Guide Version 7, GeoStudio Office, Canada, 2012.

[5] Final Report of Al-Adhaim Earth Dam, 1. Unpublished Report, Consulting Engineering Bereau, College of Engineering, University of Baghdad, 1994. 
Journal of University of Babylon for Engineering Sciences, Vol. (27), No. (1): 2019.

\section{الخلاصه}

تتم عمايه كسر السد بسبب الطفح حيث هي واحده من أكثر انواع الفثل شيوعاً في التعليات الترابيه. في هذه الدر اسه

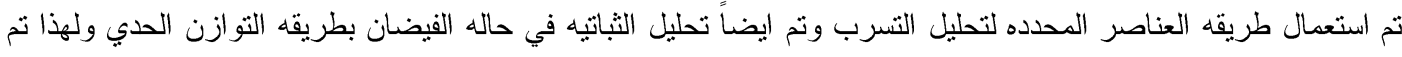
اختيار سد العظيم لعمليه التحليل خلال فتره SEEP/W,SLOPE/W من خلال بر امجها الفرعيه

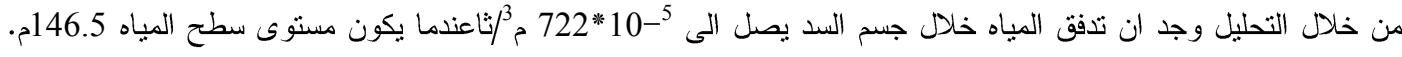
من خلال تحليل التسرب وجد انه عند مستوى المياه الاقصى فانه يزداد بمقدار 38.3\% ما هو عليه في حاله مستوى المباه

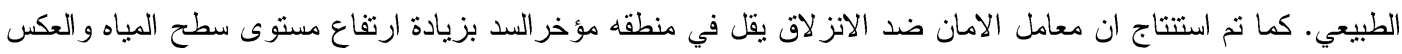

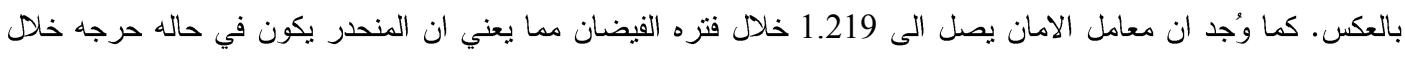

هذه الفتره. الكلمات الداله: سد نز ابي منطبق، فثل، فيضان، كسر السد. 